\title{
DIGITÁLNÍ KNIHOVNY V ČESKÉ REPUBLICE
}

PhDr. Martina Machátová; Martina.Machatova@mzk.cz; (Moravská zemská knihovna v Brně)

Hlavním cilem tohoto přispěvku je poskytnout přehled o současné situaci v oblasti digitálních knihoven v České republice. Díky grantu vznikla Národní digitální knihovna. Digitalizaci se začaly kromě Národní knihovny ČR, Moravské zemské knihovny v Brně a Knihovny Akademie věd ČR věnovat také další knihovny, které využivají ke zpřistupnění dokumentů především systém Kramerius, unikátní software vyvinutý v České republice. Tento nástroj využívaji 43 digitální knihovny. Několik z nich lze souběžně prohledávat prostréednictvím České digitální knihovny. S cílem zabránit duplicitní digitalizaci dokumentů byla vytvořena databáze Registr digitalizace. $V$ ČR vzniklo také několik oborově zaměřených digitálních knihoven.

https://doi.org/10.52036/1335793X.2021.3-4.22-27

K rozmachu digitalizace $v$ českých knihovnách významně přispěl projekt Vytvoření Národní digitální knihovny, jehož nositelem byla Národní knihovna ČR v Praze a jejím partnerem Moravská zemská knihovna v Brně. Při přípravě projektu se předpokládalo, že se do konce r. 2019 zdigitalizuje 50 milionů stran části bohemikální produkce vydané od 19. do 21. století (Národní knihovna České republiky, (C) 2012). V rámci tohoto projektu, který probíhal v letech 2010 - 2014, se podařilo vybudovat digitalizační pracoviště a zpřístupnit více než 26 milionů stran (Národní knihovna České republiky, 2015, s. 11). Od r. 2015 následovalo pětileté období udržitelnosti projektu. Byl tak vytvořen základ Národní digitální knihovny, která je i nadále doplňována. Kromě výše uvedených knihoven se začaly věnovat digitalizaci i některé krajské, městské, vysokoškolské a specializované knihovny. A. Brožek (2021) uvádí, že v prosinci 2020 existovaly celkem 72 digitálních knihoven.

Ukázalo se, že zdroje na digitalizaci jsou omezené, proto knihovny zvažují, jak dál a podle kterých kritérií vybírat dokumenty k digitalizaci (Hruška aj., 2017, s. 3, 6). $\checkmark$ současnosti se $v$ rámci Koncepce rozvoje knihoven 2021 - 2027 připravuje národní strategie digitalizace knihovních fondů ČR (Foltýn, 2021; Bežová, 2021). Výběr dokumentů k digitalizaci v Národní knihovně ČR vychází v současnosti ze Strategie digitalizace novodobých dokumentů NK ČR pro léta 2021 - 2023 (Národní knihovna České republiky, [b. r.]), v Moravské zemské knihovně v Brně se $v$ těchto dnech dokončuje strategie digitalizace na 5 let.

\section{SYSTÉM KRAMERIUS}

https://system-kramerius.cz/

Většina českých knihoven ČR využívá pro zpřístupňování digitálních dokumentů různé verze systému Kramerius, který vyvíjí Knihovna Akademie věd ČR ve spolu- práci s Národní knihovnou ČR a Moravskou zemskou knihovnou v Brně jakožto open source. Přehled digitálních knihoven, ve kterých je využit systém Kramerius od verze 4, obsahoval k 30. 6. 2021 odkazy na 43 digitálních knihoven, z nichž jedna je ve Slovenské republice - Slovenská národná knižnica (Registr Krameriů, 2021). Dle Registru bylo k uvedenému datu zdigitalizováno 679130 dokumentů, z nichž je 138287 titulů přístupno veřejně, což znamená, že kdokoliv se dostane zdarma k plnému textu zdigitalizovaného dokumentu, tedy i z počítačů mimo knihovnu. Podařilo se vyvinout aplikaci pro operační systém iOS a Android, tudíž uživatelé mohou přistupovat do digitálních knihoven na bázi Krameria také prostřednictvím mobilních zařízení. Další vývoj systému Kramerius je financován z projektů NAKI a VISK, jež jsou vyhlašovány Ministerstvem kultury ČR. Knihovny pochopitelně stále usilují o co nejjednodušší a nejpohodlnější práci v digitálních knihovnách, a to jak pro uživatele, tak i pro pracovníky digitalizace (Lhoták, 2020; Lhoták a Herudková, 2021). V současné době se pracuje na 7. verzi Krameria, kterou testuje především Moravská zemská knihovna v Brně (Lhoták a Herudková, 2021). Detailní statistické údaje a přehled vývoje systému Kramerius a digitálních knihoven v ČR publikuje každé dva roky v časopisu Čtenář Aleš Brožek. Poslední analýza byla provedena za r. 2019 (Brožek, 2020b).

Velkou předností systému Kramerius je schopnost plnotextového vyhledávání, a to jak v celé digitální knihovně, tak i v určitém dokumentu. $V$ současnosti už využívají mnohé digitální knihovny verzi 5 . Výsledky je možné zpřesňovat pomocí několika kritérií, jejichž nabídka je k dispozici po levé straně nalezených výsledků. Na digitalizované publikace Ize upozornit zájemce formou předem vybraných kolekcí, uživatelé mají k dispozici rejstříky. Čtenáři si mohou jednotlivé stránky zvětšit. 


\section{AUTORSKÁ PRÁVA}

Přístup $\mathrm{k}$ plným textům zdigitalizovaných dokumentů se opírá v Česku o zákon č. 121/2000 Sb. a jeho novelizace (Česko, 2021). Veřejně mohou být zpř́stupněna díla vydaná 70 let po smrti všech autorů a 50 let od vydání. Přístup $\mathrm{k}$ veřejným dílům umožňují knihovny $v$ České republice komukoliv bez nutnosti registrace, přihlášení či osobní návštěvy dané knihovny. Uživatelé musejí počítat s tím, že neveřejná díla jsou přístupná výhradně registrovaným uživatelům na počítačích dané knihovny.

\section{REGISTR DIGITALIZACE}

\section{http://www.registrdigitalizace.cz/}

Aby nedocházelo $\mathrm{k}$ duplicitní digitalizaci téhož díla $v$ rámci českých knihoven, byl uveden v r. 2008 do provozu Registr digitalizace. Tato databáze vznikla na základě projektu Knihovny akademie věd ČR, Národní knihovny ČR a firmy INCAD (Dvořáková, 2014). V současné době zajištuje její provoz Národní knihovna ČR. Databáze slouží především pracovníkům z oblasti digitalizace, nicméně tento zdroj je veřejně přistupný a kdokoliv zde může zjistit, zda určitý dokument byl vybrán k digitalizaci, zda probíhá jeho digitalizace či zda už byl zdigitalizován. Současně se uživatel dostane prostřednictvím linků $v$ záznamu do přislušné digitální knihovny a k podrobným bibliografickým údajům v OPAC-u dané knihovny. Bohužel prímo v Registru nezjistíme, zda je digitalizovaný dokument veřejně př́stupný či nikoliv. Registr digitalizace nabízí jednoduché a rozšířené vyhledávání. Ze zkušeností vyplývá, že při vyhledávání lze $v$ této databázi používat hvězdičku jako náhradu za libovolný počet znaků a otazník nahrazující žádný nebo jeden znak. Fungují zde rovněž oboustranné horní uvozovky pro zadání fráze (přesného slovního spojení). Rozšiřená vyhledávácí maska umožňuje zadat dotaz $v$ konkrétních polích. Jméno autora je nutné uvést $v$ invertované podobě, tzn. nejprve přijmení, pak křestní jméno. Registr digitalizace obsahuje odkazy na další zdroje (včetně zahraničních), v nichž lze hledat digitalizovaná bohemika.

\section{ČESKÁ DIGITÁLNÍ KNIHOVNA - ČDK \\ https://www.czechdigitallibrary.cz/cs/}

Existence několika desítek digitálních knihoven v České republice komplikuje uživatelům prístup ke zdigitalizovaným dokumentům. Jestliže hledáme konkrétní publikaci, nahlédneme do Registru digitalizace. Pokud přesně nevíme, který dokument hledáme, je vhodné použít Českou digitální knihovnu, národní agregátor digitálních knihoven v ČR. Tento zdroj umožňuje souběžné prohledávání několika digitálních knihoven na bázi Kramerius na jednom místě. $V$ současnosti je zde za- pojeno 14 digitálních knihoven. Praxe při vyhledávání konkrétních titulů a porovnání některých statistických údajů ukazuje, že ne všechny digitální knihovny uvedené v seznamu digitálních knihoven zapojených do ČDK jsou zde podchyceny $v$ úplnosti. Doufejme, že do budoucna bude možné zapojit do ČDK další české digitální knihovny na bázi Kramerius a v komplexnosti. O vývoj ČDK se zasloužila Knihovna Akademie věd ČR, jež doposud tento integrátorský nástroj i nadále spravuje.

Dotaz Ize zadat nejen v základní, ale také v pokročilé rešeršní masce. Systém umožňuje používat logické operátory AND, OR a NOT a oboustranné horní uvozovky pro frázi. Lze zde také uvést hvězdičku jakožto náhradu za prázdný či libovolný počet znakủ či otazník jako náhradu za jeden znak. $V$ pokročilém vyhledávacím rozhraní je možné napsat dotaz v určitém poli. Dotaz Ize zpřesnit pomocí kritérií, jejichž nabídku uvidíte po levé straně obrazovky (dostupnost, typ dokumentu, klíčová slova, autor, jazyk, knihovna, místo uložení, rok vydání). $\checkmark$ pravé horní ćásti obrazovky jsou k dispozici pod záložkou „procházet“ rejstříky. Jednotlivé položky jsou zde řazeny podle četnosti, doporučuji navolit abecední řazení. Nejvíce asi oceníme rejstřík autorů. Nalezené výsledky jsou standardně seřazeny podle relevance, ale je možné navolit jiné uspořádání pomocí nabídky v pravé horní části obrazovky. Systém umí vygenerovat citaci, zvětšit, zmenšit či otočit požadovanou stranu či vytvořit textový přepis celé strany nebo vybraného úseku strany. Bohužel ne u všech dokumentů lze zobrazit textový přepis, někdy vykazuje textový přepis nedostatky. Uživatelé si mohou u veřejných děl vygenerovat vybrané strany ve formátu PDF nebo vybrat stránky k tisku (nanejvýš 20 stran). Systém rovněž umožňuje vygenerovat určitou stranu ve formátu JPEG.

\section{DIGITÁLNÍ KNIHOVNY NÁRODNÍ KNIHOVNY ČR}

https://www.nkp.cz/digitalni-knihovna/digitalni-knihovny

Nejrozsáhlejší digitální knihovny spravuje v Česku Národní knihovna ČR a Moravská zemská knihovna v Brně. Obsahově se tyto digitální knihovny prekrývají asi ze $70 \%$ (Smetánková, 2021). Převážnou část uživatelů bude pravděpodobně zajímat Národní digitální knihovna (NDK), v níž je využit systém Kramerius verze 5 . Zájemci zde mohou pracovat $v$ podobném prostředí jako v České digitální knihovné. Uživatel si může naráz vytisknout nanejvýš 60 vybraných stran. Na rozdíl od ČDK Ize zde nahlédnout pro inspiraci do předem připravených kolekce dokumentů, jež najdete pod záložkou "sbírky" v pravé horní ćásti webové stránky. Jsou zde k dispozici skupiny publikací podle žánrů či dle témat. Před hackerskými útoky bylo možné hledat v NDK (Kramerius verze 
5) také dokumenty z verze 3 . Dokumenty digitalizované do r. 2011 jsou prístupné prostřednictvím Krameria verze 3., který není tak uživatelsky přívětivý jako Kramerius verze 5 v NDK. Do hackerských útoků na web Národní knihovny ČR bylo možné zadat dotaz pro vyhledávání $\checkmark$ dřive digitalizovaných dokumentech prostřednictvím Krameria verze 5 . Kramerius verze 3 nabízí základní a pokročilé vyhledávání. Bohužel naskenované dokumenty jsou zde ve formátu DjVu, takže k jejich otevření je nezbytné nainstalovat príslušný plugin, s čímž mohou mít někteří uživatelé problémy. 20 vybraných stránek je možné vygenerovat do formátu PDF. Postupně jsou knihy z Krameria verze 3 preváděny do vyšší verze 5 .

Přes webovou stránku Národní knihovny ČR Ize se také dostat do digitální knihovny evropského kulturního dědictví Manuscriptorium, která se zaměřuje na historické fondy, jež jsou uloženy $v$ různých pamětových institucích. Pomocí Webarchivu se Ize dostat k starším informacím na webových stránkach institucí, které podepsaly smlouvu s Národní knihovnou ČR. Po odkliknutí se objeví kalendář s vyznačenými daty a hodinami archivace př́slušného webu.

\section{DIGITÁLNÍ KNIHOVNA MORAVSKÉ ZEMSKÉ KNIHOVNY V BRNĚ \\ http://www.digitalniknihovna.cz/mzk}

Digitální knihovna Moravské zemské knihovny v Brně zatím nenabízí pokročilé vyhledávací rozhraní, nelze zde ani pracovat s logickými operátory, ale na rozdíl od České digitální knihovny a Národní digitální knihovny umožňuje geografické vyhledávání, což jistě ocení zájemci o mapy. Uživatelé mají možnost v této knihovně zobrazit si pouze výřez určité strany. I zde můžete pracovat s rejstříky a inspirovat se pomocí předvybraných skupin dokumentů (viz záložka „sbírky“). Uživatelé si mohou naráz vytisknout až 100 vybraných stran. Jsou tu také k dispozici odkazy na některé další digitální knihovny na bázi systému Kramerius.

\section{DÍLA NEDOSTUPNÁ NA TRHU - DNNT}

Registrovaní čtenáři knihoven, které podepsaly smlouvu s Národní knihovnou ČR, se mohou dostat po prihlášení odkudkoliv $\mathrm{k}$ plným textům tzv. děl nedostupných na trhu. Jedná se o dokumenty, u nichž ještě neuplynulo 70 let od smrti všech autorů a 50 let od vydání, ale které už nelze koupit v běžné obchodní síti. Uživatelé s platnou čtenářskou legitimací tak mají v současnosti př́stup k celé řadě knih vydaných do r. 2000 (vzdálený prístup) či od r. 2001 do r. 2007 (na místě samém) a k periodikům do r. 2010 (vzdálený prístup) (Richter, 2021). Př́stup k DNNT je možný díky dohodě mezi kolektivními správci autorských práv (DILIA, OOA-S), Sva- zem českých knihkupců a nakladatelů, Národní knihovnou ČR a Ministerstvem kultury, které bude poskytovat kolektivním správcům autorských práv finanční odměnu za poskytnutí licence. Zatím platí tato dohoda do r. 2023. Uživatelé nemohou díla nedostupná na trhu tisknout ani stahovat. Registrovaní čtenáři některých knihoven a studenti a pedagogové vysokých škol měli od jara 2020 do konce června 2021 po přihlášení vzdálený př́stup $\mathrm{k}$ plnému obsahu vybraných digitálních knihoven, a to díky pochopení kolektivních správců autorských práv a Svazu českých nakladatelů a knihkupců. $\mathrm{V}$ důsledku nové smlouvy $\mathrm{s}$ kolektivním správcem autorských práv DILIA došlo ke změně v oblasti volného př́istupu $k$ periodikům. $V$ současné době zpřístupňuje veřejně Národní knihovna ČR a Moravská zemská knihovna periodika starší 110 let.

Národní knihovna ČR buduje databázi Seznam děl nedostupných na trhu, která je veřejně př́stupná v systému ALEPH (Národní knihovna České republiky, 2021). Návrhy na zařazení dokumentu do této databáze mohou vznést nositelé práv (autoři a jejich dědicové, nakladatelé), kolektivní správci autorských práv nebo knihovny. Dílo je vedeno jakožto návrh na zařazení do seznamu po dobu minimálně 6 měsíců. Nositelé práv mohou požádat o vyřazení díla ze seznamu.

V období covidu pochopitelně vzrostl zájem uživatelů o prístup ke zdrojům v elektronické podobě (Vozár, 2020; Vozár, 2021). V r. 2020 bylo zobrazeno a staženo 38,2 mil. dokumentů (Závěrečná zpráva..., [2021], s. 7).

\section{SPECIÁLNÍ DIGITÁLNÍ KNIHOVNY V ČR}

Česká digitální matematická knihovna:

https://dml.cz/

Bibliotheca economica:

https://bibliothecaeconomica.cz/

Digitální knihovna časopisů Ústavu pro českou

literaturu AC ČR:

http://archiv.ucl.cas.cz/

Národní fonotéka:

https://narodnifonoteka.cz/

eSbírky:

https://www.esbirky.cz/

V České republice vzniklo i několik oborových digitálních knihoven, které se opírají o jiný software než Kramerius. Dlouholetou tradici má Česká digitální matematická knihovna DML-CZ, která obsahuje matematickou literaturu publikovanou v českých zemích od 19. století do současosti do současosti. Všechny dokumenty obsažené v této digitální knihovně jsou zdarma př́stupné 
veřejnosti bez nutnosti registrace a přihlášení. Základy DML-CZ položil projekt řešený v letech 2005 - 2009. Kromě monografií a periodik jsou zde $k$ dispozici rovněž sborníky z konferencí a literatura spojená se známými českými matematiky. Všechny dokumenty (včetně novějších) jsou zde zdarma př́stupné v plném textu. Periodika a sborníky z konferencí se zobrazují ve formě jednotlivých př́spěvků ve formátu PDF. Monografie Ize rovněž studovat prostřednictvím jednotlivých kapitol ve stejném formátu. Uživatelé mají $k$ dispozici rejstřík sbírek, autorů a názvů. Pokud neumějí přesně formulovat dotaz, mohou se dostat $k$ požadovaným dokumentům i za pomoci systematického třídníku pro matematické obory (Mathematics Subject Classification - MSC). Kromě základního vyhledávání lze zadat dotaz v pokročilé rešeršní masce.

Zájemci o historický vývoj českého ekonomického myšlení jistě ocení virtuální knihovnu Bibliotheca economica, která obsahuje knihy a časopisy vydané do r. 1948. Do elektronické knihovny se vstupuje přes katalog, $v$ němž je jednak možné hledat podle různých kritérií, jednak tu uživatel může nahlédnout do abecedního rejstříku autorů, názvů knih a klíčových slov, prípadně do přehledu ročníků časopisů a klíčových slov.

Jednou z prvních českých digitálních knihoven v ČR je Digitální knihovna časopisů Ústavu pro českou literaturu AV ČR, která vznikla v r. 2001 a obsahuje několik desítek titulů periodik. Jsou zde $k$ dispozici tři masky pro vyhledávání: dle autorů a názvů článků, dle chronologického vymezení a rozhraní pro prímý přístup ke konkrétnímu číslu a stránce určitého titulu.

Knihovny v Česku usilují o digitalizaci nejen knih a periodik, ale také dalších typů dokumentů. Národní technická knihovna v Praze spravuje portál Národní fonotéka (před r. 2020 pod názvem Virtuální národní fonotéka), který se specializuje na zvukové dokumenty. Portál obsahuje záznamy zvukových nahrávek uložených $v$ různých pamětových institucích ČR. Některé zvukové nahrávky si Ize prostřednictvím portálu i poslechnout, pokud to umožňuje autorskoprávní legislativa.

Digitalizací se v České republice zabývají také ostatní pamětové instituce, např. archivy, muzea a galerie. Archivy usilují především o digitalizaci matrik. Informace o projektech jednotlivých archivů najdete na webu ČGHSP (Česká genealogická ..., (C) 2015). Exponáty ze 167 českých muzeí a galerií zachycuje portál eSbírky, jenž spravuje Národní muzeum v Praze.

VZDĚLÁVÁNÍ KNIHOVNÍKŮ V OBLASTI DIGITALIZACE Moravská zemská knihovna v Brně (MZK) pořádá každoročně za podpory Sdružení SDRUK seminář (Sdružení knihoven ČR, [b.r.]). Uvedená knihovna rovněž přiležitostně realizuje e-learningový kurz $v$ prostředí Moodle za podpory VISK. V MZK se podařilo na podzim 2020 uskutečnit první běh kurzu Samostatný knihovník správce digitální knihovny. Hlavním cílem tohoto kurzu bylo připravit posluchače ke zkouškám v rámci Národní soustavy kvalifikací, obsah kurzu vycházel tedy z príslušného hodnotícího standardu (Samostatný knihovník..., 2006 - 2014). S ohledem na ochranná opatření proti šíření covidu proběhla větší část kurzu formou online a uchazeči o uvedenou profesní kvalifikaci byli vyzkoušeni až v červnu 2021.

\section{VÝZVY DO BUDOUCNOSTI}

Digitalizace fondů knihoven v České republice pokračuje mílovými kroky. Zájemci mají $k$ dispozici několik set tisíc titulů v digitalizované formě, at' už se jedná o dokumenty přístupné vzdáleným uživatelům, nebo pouze na počítačích dané knihovny. Řada států má Česku co závidět, nicméně při hledání v digitálních knihovnách narážíme i na některé nedostatky.

Musím souhlasit s A. Brožkem (2020a; 2021), že závažným problémem nejen pro čtenáře, ale také pro knihovníky, je existence několika desítek digitálních knihoven v České republice. Snad se postupně odstraní překážky technického rázu a podaří se integrovat do České digitální knihovny většinu jednotlivých digitálních knihoven, které fungují na bázi Krameria. Jestliže $v$ současnosti potřebujeme zjistit, zda určitý titul byl zdigitalizován a ve které digitální knihovně se nachází, Ize to zkusit prímo v největších digitálních knihovnách, nebo pomocí dalších databází. Kromě Registru digitalizace, o jehož existenci pravděpodobně většina čtenářů nemá povědomí, obsahuje odkazy na digitalizovanou podobu portál Knihovny.cz nebo Souborný katalog ČR. Jestliže se chceme dostat $k$ veřejným digitalizovaným publikacím, zpřesníme na portále Knihovny.cz dotaz pomocí filtru "typ výpůjčky", kde v nabídce zvolíme „online" a „dostupné". Po otevření záznamu je nezbytné kliknout v jeho spodní části na tlačítko "e-verze“.

V Souborném katalogu ČR v systému ALEPH dotaz omezíme "druhem dokumentu“, v nabídce odklikneme „digitalizované dokumenty", ale je nutné počítat $\mathrm{s}$ tím, že výsledek bude obsahovat jak záznamy s odkazy na veřejná díla, tak i záznamy s odkazy na neveřejné publikace.

Občas uživatelé narazí na problém neúplnosti. U některých periodik chybějí v určité digitální knihovně např. některé ročníky či u vícesvazkového díla určité svazky. Porovnejte si např. dostupnost jednotlivých ročníků časopisu Vesmír v Národní digitální knihovně, v digitální knihovně Moravské zemské knihovny v Brně, Knihovny Akademie věd ČR a Knihovny A. Švehly (součást ÚZEI), 
do kterých se dostanete pomocí odkazů v Registru digitalizace. I když v digitální knihovně Knihovny A. Švehly najdete pouze jeden ročník časopisu Vesmír, Souborný katalog ČR (CASLIN) do této digitální knihovny neodkazuje, ale portál Knihovny.cz ano. U Toulek českou minulostí dosud nebyl zdigitalizován 11. díl z r. 2007, ačkoliv 12. díl z r. 2009 a 13. díl z r. 2012 už zdigitalizován byl a je $\mathrm{k}$ dispozici $v$ neveřejném režimu $v$ digitální knihovně Národní knihovny ČR a v Moravské zemské knihovny v Brně. A. Brožek (2021) upozornil např. na to, že vícesvazkový Lexikon české literatury je třeba hledat ve dvou digitálních knihovnách. Při hledání konkrétních digitalizovaných titulů je tak často nezbytné kombinovat různé elektronické zdroje. Jako názorný př́klad doporučuji skvělý příspěvek A. Brožka (2016).

Musíme počítat také s tím, že některá bohemika jsou k dispozici v zahraničních digitálních knihovnách. Asi ne každého napadne, že např. periodika Der Böhmische Bierbrauer, Český esperantista či Cecílie najde v digitální knihovně ANNO, kterou buduje Rakouská národní knihovna ve Vídni. Zvukovou nahrávku projevu T. G. Masaryka $k$ parlamentu a dětem najdete pro změnu v Digital Public Library of America a staré mapy Brna v digitální knihovně Gallica.

U dřive zdigitalizovaných dokumentů nefunguje v Krameriovi textový přepis stránky nebo její výseče. U nové digitalizace se občas vyskytují v textovém přepisu chyby.

\section{ZÁVĚR}

České knihovny mohou být právem hrdé na výsledky dosažené v digitalizaci svých fondů, je zde ovšem stále na čem pracovat, a to jak po stránce kvantitativní, tak i kvalitativní. Uživatelé se díky digitálním knihovnám dostanou k informacím, které by byly ručním listováním papírovým dokumenty velmi obtížně dohledatelné. Oblast digitalizace přináší řadu výhod pro čtenáře, ale také značné množství podnětů a přiležitostí pro další zdokonalování a výzkum v knihovnách.

\section{DŮLEŽITÉ ODKAZY}

Česká digitální knihovna [národní integrátor digitálních knihoven, souběžné prohledávání několika digitálních knihoven]:

https://www.czechdigitallibrary.cz/cs/

Digitální knihovna [odkazy na některé digitální knihovny v ČR]:

http://www.digitalniknihovna.cz/

Digitální knihovna Knihovny Akademie věd ČR

http://www.digitalniknihovna.cz/knav

Digitální knihovna Moravské zemské knihovny v Brně

http://www.digitalniknihovna.cz/mzk
Národní digitální knihovna [digitální knihovna Národní knihovny ČR]:

Původní vyhledávací rozhraní:

https://www.ndk.cz/

Nové vyhledávací rozhraní:

https://kramerius5.nkp.cz/

Registr digitalizace [informace o stavu digitalizace jednotlivých dokumentů, odkazy na zdigitalizované dokumenty v různých digitálních knihovnách]:

http://www.registrdigitalizace.cz/

Registr Krameriů [přehled digitálních knihoven, které fungují na bázi systému Kramerius] :

https://registr.digitalniknihovna.cz/

https://registrkrameriu.mzk.cz/

\section{ZKRATKY}

ČDK Česká digitální knihovna

ČGHSP Česká genealogická a heraldická společnost v Praze

DNNT Díla nedostupná na trhu

NAKI Program na podporu aplikovaného výzkumu a vývoje národní a kulturní identity

NDK Národní digitální knihovna

SDRUK Sdružení knihoven ČR

ÚZEI Ústav zemědělské ekonomiky a informací

VISK Veřejné informační služby knihoven

Použité zdroje

BEŽOVÁ, Michaela, (C) 2021. Kroky k př́pravě strategie digitalizace českých knihoven. In: SlideShare [online]. San Francisco: Scribd [cit. 2021-06-30] Dostupné z: https://www.slideshare.net/secret/ C1aK7NQcx6x4id. Prezentace $k$ příspěvku předneseném na online Semináŕi k digitalizaci (nejen) pro krajské knihovny 2021 dne 2. 6. 2021.

BROŽEK, Aleš, 2016. Nenašli jsme Peroutkův článek... . In: YouTube [online]. Google, 8. 12. 2016 [cit. 2021-06-30]. Dostupné z: https:// www.youtube.com/watch?v=tInLUaUAJdE. Videozáznam príspěvku předneseného na 17. konferenci Archivy, knihovny, muzea v digitálním světě 2016 dne 30. 11. 2016.

BROŽEK, Aleš, 2020a. Můžeme být spokojeni s digitalizací knihovních fondů v České republice a jejím využitím? Duha: informace o knihách a knihovnách z Moravy [online]. Brno: Moravská zemská knihovna v Brně, roč. 34, č. 1 [cit. 2021-07-12]. ISSN 1804-4255. Dostupné z: http://duha.mzk.cz/clanky/muzeme-byt-spokojeni-s-digitalizaci-knihovnich-fondu-v-ceske-republice-jejim-vyuzitim BROŽEK, Aleš, 2020b. Systém Kramerius v knihovnách ČR na konci roku 2019. Čtenář: měsičník pro knihovny. Kladno, Středočeská vědecká knihovna v Kladně, roč. 72 č. 4, s. 142-144. ISSN 0011-2321. Dostupné také z: https://svkkl.cz/ctenar/clanek/3082

BROŽEK, Aleš, 2021. Potřebujeme další digitální knihovny (DK)? [prezentace]. In: Elektronické služby knihoven - konference VI: 18.-19. května 2021 [online]. Krajská knihovna Františka Bartoše 
ve Zlíně, [cit. 2021-06-01]. Dostupné z: https://www.kfbz.cz/sites/ default/files/souboryredakce/brozek_jedna_dk_compressed.pdf. Záznam 1. dne konference s příspěvkem A. Brožka dostupný z: https://www.youtube.com/watch?v=SqyEUIJhRjc

ČESKÁ GENEALOGICKÁ A HERALDICKÁ SPOLEČNOST V PRAZE, (C) 2015. Matriky na Internetu. Česká genealogická a heraldická společnost v Praze [online]. Praha: Česká genealogická a heraldická společnost v Praze, [cit. 2021-07-01]. Dostupné z: http://www. genealogie.cz/aktivity/digitalizace/

ČESKO, 2021. Zákon č. 121/2000 Sb. Zákon o právu autorském, o právech souvisejících s právem autorským a o změně některých zákonů (autorský zákon): aktuální znění 27. 2. 2021 - 27. 12. 2021 (verze 22). In: Zákony pro lidi [online]. Zlín: AION CS, 2010 - 2021 [cit. 2021-06-07]. Dostupné z: https://www.zakonyprolidi.cz/ CS/2000-121

DVOŘÁKOVÁ, Helena, 2014. Registr digitalizace. Ikaros [online] Praha: Ikaros, roč. 18, č. 3 [cit. 2021-05-05]. urn:nbn:cz:ik-14208. ISSN 1212-5075. Dostupné z: http://ikaros.cz/node/14208

FOLTÝN. Tomáš, 2021. Př́prava strategie digitalizace knihovních fondů v ČR a další plánované aktivity Národní knihovny ČR v oblasti digitalizace a zpř́stupnění digitálního obsahu. In: YouTube [online]. Google, 8. 6. 2021 [cit. 2021-06-30]. Dostupné z: https://www.youtube.com/watch?v=tInLUaUAJdE. Videozáznam 1. dne konference Elektronické služby knihoven - konference VI včetně příspěvku T. Foltýna předneseného 18. května 2021.

HRUŠKA, Zdeněk aj., 2017. Strategie digitalizace v Moravské zemské knihovně v Brně [online]. Verze 1. [Brno]: Moravská zemská knihovna v Brně, 22. 2. 2017 [cit. 2021-06-29]. Dostupné z: https://www. mzk.cz/sites/mzk.cz/files/souboryMzK/pdf/strategie_digitalizace_ mzk_02-2017_v1-0.pdf

LHOTÁK, Martin, 2020. DL4DH - Digital libraries for digital humanities: nový projekt na vytěžování obsahu digitálních knihoven. IT lib: informačné technológie a knižnice [online]. Bratislava: Centrum vedecko - technických informácií SR, roč. 24, č. 4, s. 27-31 [cit. 2021-07-01]. ISSN 1336-0779. Dostupné z: https://itlib.cvtisr.sk/ wp-content/uploads/2021/02/Lhotak.pdf.

LHOTÁK, Martin a Markéta HERUDKOVÁ, 2021. Kramerius, ProArc, ARCLib - aktuální stav a plánovaný rozvoj [prezentace]. In: Elektronické služby knihoven - konference VI: 18.-19. května 2021 [online]. Krajská knihovna Františka Bartoše ve Zlíně, [cit. 2021-06-01]. Dostupné z: https://www.kfbz.cz/sites/default/files/souboryredakce/lhotak_2021-el._sluzby_knihovnam.pdf. Záznam 1. dne konference s příspěvkem $M$. Lhotáka dostupný z: https://www.youtube. com/watch?v=SqyEUIJhRjc

NÁRODNÍ KNIHOVNA ČESKÉ REPUBLIKY, [b. r.]. Strategie digitalizace novodobých dokumentů NK ČR pro léta 2021-2023 [online]. [Praha: Národní knihovna ČR], [cit. 2021-06-28]. Dostupné z: https:// text.nkp.cz/soubory/ostatni/StrategieDigitalizaceNovodobychDokNK_20212023_final.pdf

NÁRODNÍ KNIHOVNA ČESKÉ REPUBLIKY, @ 2012. Národní digitální knihovna. Národní knihovna České republiky [online]. Praha: Národní knihovna ČR, [cit. 2021-06-29]. Dostupné z: https://text.nkp. cz/o-knihovne/zakladni-informace/narodni-digitalni-knihovna NÁRODNÍ KNIHOVNA ČESKÉ REPUBLIKY, 2015. Výroční zpráva 2014. Praha: Národní knihovna České republiky, [cit. 2021-06-15]. ISSN 1804-8625. Dostupné z: https://www.nkp.cz/soubory/ostatni/ vz2014.pdf

NÁRODNÍ KNIHOVNA ČESKÉ REPUBLIKY, 2021. Seznam děl nedostupných na trhu. Národní knihovna České republiky [online]. Praha: Národní knihovna ČR, 1. 7. 2021 [cit. 2021-07-02]. Dostupné z: https://dnnt.nkp.cz/seznam.html

Registr Krameriů [online], 2021. Posledni obnova 30.06.2021 [cit. 2021-06-30]. Dostupné z: https://registr.digitalniknihovna.cz/

RICHTER, Vít, 2021. Zpř́stupnění děl nedostupných na trhu - současnost a perspektivy [prezentace]. In: Elektronické služby knihoven - konference VI: 18.-19. května 2021 [online]. Krajská knihovna Františka Bartoše ve Zlíně, [cit. 2021-07-05]. Dostupné z: https:// www.kfbz.cz/sites/default/files/souboryredakce/dilanedostpnatrhu_05_2021_zlin_esluzby.pdf. Záznam 1. dne konference s príspěvkem V. Richtera dostupný z: https://www.youtube.com/watch?v=SqyEUIJhRjc

Samostatný knihovník správce digitální knihovny (kód: 72-018R), 2006 - 2014. In: Národní soustava kvalifikací [online]. Verze 2.1.4399.27657. Praha: Národní pedagogický institut České republiky, [cit. 2021-06-29]. Dostupné z: https://www.narodnikvalifikace.cz/kvalifikace-1132-Samostatny_knihovnik_spravce_digitalni_knihovny/revize-3297

SDRUŽENÍ KNIHOVEN ČR, [b. r.]. Sekce pro informační technologie. SDRUK [online]. Praha: Sdružení knihoven ČR, [cit. 2021-07-01]. Dostupné z: https://sdruk.cz/odborne-sekce/sekce-pro-informacnitechnologie/

SMETÁNKOVÁ, Martina, 2021 [Digitální knihovna]. In: KRČÁL, Martin, Iva ZADRAŽILOVÁ a Martina SMETÁNKOVÁ. E-knihy na portálech Knihovny.cz a Digitální knihovna: online seminář konaný 23. března 2021 [online]. Brno: Moravská zemská knihovna v Brně, 23. března 2021 [cit. 2021-06-05]. Nebyl pořízen záznam tohoto semináře.

VOZÁR, Zdenko, 2020. Digitální knihovna v době virové - služba dnes studentům, zítra široké veřejnosti. Knihovna: knihovnická revue [online]. Praha: Národní knihovna ČR, roč. 31, č. 1 [cit. 2021-0701]. ISSN 1802-8772. Dostupné z: https://knihovnarevue.nkp.cz/ archiv/2020-1/knihovny-a-informace/digitalni-knihovna-v-dobe-virove-2013-sluzba-dnes-studentum-zitra-siroke-verejnosti

VOZÁR, Zdenko, 2021. Digitálna knižnica v dobe vírovej II. - Vývoj a služba národného systému sprístupňovania diel. Knihovna: knihovnická revue [online]. Praha: Národní knihovna ČR, roč. 32, č. 1, s. 43-58 [cit. 2021-07-02]. ISSN 1802-8772. Dostupné z: https:// knihovnarevue.nkp.cz/archiv/2021-1/knihovny-a-informace-doma -a-ve-svete/digitalna-kniznica-v-dobe-virovej-ii

Závěrečná zpráva o plnění Koncepce rozvoje knihoven v České republice na léta 2017 - 2020 [online], [2021]. [Praha: Národní knihovna ČR], [cit. 2021-07-19]. Dostupné z: https://ipk.nkp.cz/ docs/zaverecna-zprava-ke-koncepci-rozvoje-knihoven-v-cr-na-leta-2017-2020 